\title{
Acute gastroenteritis associated with norovirus Gll.4 variants
}

\author{
Fabiana Lopes de PAULA ${ }^{1,2}$, Silvia Inês SARDI', Dellane Martins TIGRE ${ }^{1,3}$, \\ Flora Maria de Campos FERNANDES ${ }^{4}$ and Gúbio Soares CAMPOS ${ }^{1}$
}

Received 19/3/2018 Accepted 23/7/2018

\begin{abstract}
Background - Norovirus (NoV) is an important etiologic agent of acute gastroenteritis and infects individuals of all ages, especially children in Brazil and worldwide. NoV GII.4 was the most prevalent genotype worldwide because of your extensive genetic diversity. In Brazil, especially in the Northeast, few studies have been developed for identify and molecularly characterize NoV. Objective - The present study aimed to detect and describe the molecular epidemiology of NoV associated with acute gastroenteritis. Methods - The viral RNA extracted from stool samples were subjected to Nested RT-PCR and the genotypes were determined by nucleotide sequences analysis. In total, 278 stool samples assisted at Aliança Hospital in the city of Salvador, with acute gastroenteritis were examined, between March 2009 and July 2012. Results - A high NoV rate (54.2\%) was identified in children under 5 years of age. We detected the circulation of different NoV GII.4 variants in Salvador, during the study period as Den Haag 2006b, New Orleans 2009 and Sydney 2012. Conclusion - These findings reinforce the need to study the molecular epidemiology of NoV infections in acute gastroenteritis.

HEADINGS - Norovirus. Gastroenteritis. Phylogeny.
\end{abstract}

\section{INTRODUCTION}

Norovirus (NoV) belonging to Caliciviridae family is recognized as a leading agents of acute nonbacterial gastroenteritis ${ }^{(1)}$. NoV infects individuals of all ages, especially children and the elderly, and rarely occurs with other viruses that cause gastroenteritis. NoV is a non-enveloped virus with icosahedral capsid morphology whose viral genome is a positive-stranded RNA of approximately $7.5 \mathrm{~kb}$ in length, organized into three open reading frames (ORF1-3). The ORF1 encodes a non-structural polyprotein, including RNAdependent RNA polymerase, a highly conserved region used for the diagnosis and identification of NoV. ORF2 and ORF3 encode the major capsid protein (VP1) and the minor structural protein (VP2), respectively ${ }^{(2)}$.

The NoV can be classified into five genogroups (GI-GV). Three of these genogroups (GI, GII and GIV) occur in human infections; however, most strains belong to GI and GII. The genogroups can be further subclassified into genotypes, with 8 genotypes found in GI (GI.1-GI.8) and 21 in GII (GII.1-GII.21). Among them, NoV GII.4 was the most prevalent genotype worldwide because of your extensive genetic diversity ${ }^{(3)}$.

In Brazil, NoV was first reported in 1993 and since then, the presence of GI and GII has been reported in several regions of the country, in the North, Midwest, Southeast and Northeast ${ }^{(4,5,6,7,8,9)}$. $\mathrm{NoV}$ is an etiologic agent frequently reported in gastrointestinal disorders in Brazil and, especially in the Northeast, few studies have been developed for this purpose. Therefore, the aim of this study was to detect and molecularly characterize NoV in stools samples of patients from the city of Salvador, Bahia, Brazil.

\section{METHODS}

We examined 1,281 stool samples from patients with acute gastroenteritis assisted at Aliança Hospital in the city of Salvador, Bahia, between March 2009 and July 2012. Of these, 321 samples were positive by serology. From the serologically positive samples, the molecular tests were performed, 278 samples being positive by RT-PCR. The definition of acute gastroenteritis used in this study was the occurrence of diarrhea and other symptoms such as vomiting, fever and abdominal pain. The Ethics Committee for Human Research of Salvador University approved this study (protocol number 04.11.12).

Viral RNA was extracted from $140 \mathrm{~mL}$ of $10 \%$ stool supernatant using the QIAmp viral RNA kit (QIAGEN, Germany), according to the manufacturer's instructions and then subjected to a nested multiplex reverse transcription polymerase chain reaction (RT-PCR) assay. Nested RT-PCR was used for the detection of the NoV RNA polymerase gene. A first-round RT-PCR was performed using outer primers CAL-32 (5'-ATGAATATGAATGAGGATGG-3') and MO3-N (5'-TCAGATGGGTCTTCATGATTGG-3'). These primers span nucleotide positions 4490-5127 of the reference sequence (M87661: Hu/NoV/GI.1/Norwalk virus/1968/US) and amplify a 638-bp outer product. The second-round of PCR was done using inner primers JV-12 (5'-ATACCACTATGATGCAGATTA-3') and ACAL-36 (5'-GACAAAACAGAAGGACCAAT-3') ${ }^{(10)}$. These inner primers generate a 428-bp final nested fragment. Amplification was performed in a GeneAmp PCR System 2400 thermal cycler (Perkin Elmer). The first-round RT-PCR cycling conditions were as follows: $48^{\circ} \mathrm{C} / 45 \mathrm{~min}$ (RT-step), $94^{\circ} \mathrm{C} / 2 \mathrm{~min}$, followed by 35 cycles

Declared conflict of interest of all authors: none

Disclosure of funding: no funding received

${ }^{1}$ Universidade Federal da Bahia (UFBA), Instituto de Ciências da Saúde, Laboratório de Virologia, Salvador, BA, Brasil. ${ }^{2}$ Universidade Federal do Recôncavo da Bahia (UFRB), Centro de Ciências da Saúde, Santo Antônio de Jesus, BA, Brasil. ${ }^{3}$ Universidade Estadual do Sudoeste da Bahia (UESB), Departamento de Ciências Biológicas, Jequié, BA, Brasil. ${ }^{4}$ Universidade Federal da Bahia (UFBA), Instituto de Biologia, Laboratório de Genética de Populações e Evolução Molecular, Salvador, BA, Brasil.

Corresponding author: Dellane Martins Tigre. Orcid: 0000-0002-7435-9986. E-mail: dellanetigre@yahoo.com.br 
of $94^{\circ} \mathrm{C} / 30 \mathrm{~s}, 37^{\circ} \mathrm{C} / 30 \mathrm{~s}$ and $68^{\circ} \mathrm{C} / 50 \mathrm{~s}$ and one extension step of $68^{\circ} \mathrm{C} / 7 \mathrm{~min}$. For the second-round PCR cycling, conditions were: $94^{\circ} \mathrm{C} / 3 \mathrm{~min}$ followed by 30 cycles of $93^{\circ} \mathrm{C} / 30 \mathrm{~s}, 37^{\circ} \mathrm{C} / 15 \mathrm{~s}, 72^{\circ} \mathrm{C} / 30 \mathrm{~s}$ plus a final extension step of $72^{\circ} \mathrm{C} / 5 \mathrm{~min}^{(10)}$. The PCR products were analyzed by electrophoresis in a $2 \%$ agarose gel and ethidium bromide staining $(1 \mathrm{mg} / \mathrm{mL})$. PCR products were purified with QIAquick ${ }^{\circledR}$ PCR purification Kit (QIAGEN, Germany) according to the manufacturer's instructions and nucleotide sequencing of the PCR products was performed by ACTgene, Biotech Center of the Universidade Federal do Rio Grande do Sul (UFRGS), using the inner primers with Big Dye Terminator ${ }^{\circledR}$ and ABI-Prism 3500 sequencer (Applied Biosystems, USA). Nucleotide sequences were aligned and edited with Clustal W software available in the BioEdit program (http://mbio.ncsu.edu/bioedit.html) Sequence Editor 7.0, and then compared with the NoV sequences published in GenBank, using the Basic Local Alignment Search Tool (BLAST) application. Phylogenetic analysis was performed by the Maximum Likelihood method based on the Kimura two-parameter model with MEGA version 6 software ${ }^{(11)}$. Statistical support for the tree was evaluated by bootstrapping based on 1000 repetitions. Nucleotide sequences obtained from this study were deposited in GenBank under accession numbers KF307752.1, KF307753.1, KF307754.1, KF307755.1, KF307756.1, KF307757.1, KF265495.1, KF265496.1 and KF265497.1.

\section{RESULTS AND DISCUSSION}

Previously we reported the molecular detection of NoV in young adults ${ }^{(6)}$ and in the present study we extended the identification of NoV in all age groups (TABLE 1). In total, 151 of the 278 stool samples were detected in children under 5 years old, identifying a high rate of infection in this age group (54.32\%) and suggesting that this is a group more susceptible to NoV infection. The high incidence of NoV infection in children seems to be related to the low preexisting NoV-specific antibodies and the decline in the cases of rotavirus infection ${ }^{(12)}$. In Brazil, after the introduction of rotavirus vaccines, has been observed this decline and the NoV has been considered as the main etiological agent of viral gastroenteritis in children ${ }^{(13)}$.

TABLE 1. Distribution of stool samples analyzed by age groups

\begin{tabular}{ccc}
\hline Age group (years) & $\mathbf{n}$ & $\%$ \\
\hline $0-5$ & 151 & 54.32 \\
$6-15$ & 34 & 12.23 \\
$16-21$ & 16 & 5.75 \\
$22-59$ & 52 & 18.70 \\
Above 60 & 25 & 9.00 \\
Total & 278 & 100 \\
\hline
\end{tabular}

Several states in Brazil reported the presence of NoV based upon sequence data of NoV strains registered in GenBank. The genetic relationship among of these strains with others characterized in the present study was established by phylogenetic analysis. The phylogenetic tree was based on the K2 model (Kimura 2-parameter) of nucleotide substitution and similarity value $-\mathrm{InL}=$ -787.546 (FIGURE 1).

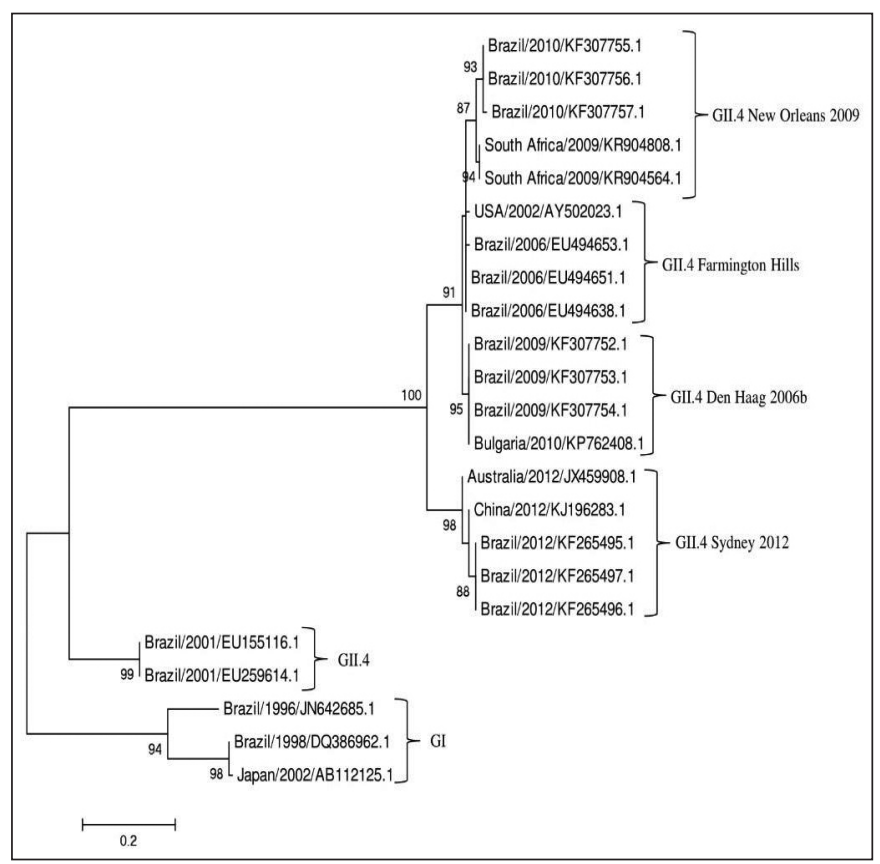

FIGURE 1. Phylogenetic tree based on a partial fragment of the RNAdependent RNA polymerase gene on human Norovirus GI and GII. Strains denomination: state of origin/year of collection/GenBank access number.

Based on this model, the phylogenetic tree revealed three distinct phylogenetic groups. The GI group was used as an out group and the strains of the GII.4 group displayed divergences in sequence alignment which led to the separation into two distinct groups. Previously, we reported the genetic diversity of NoV and suggested that GII.4 is a predominant circulating genotype in NoV outbreaks in Brazil ${ }^{(6)}$. The predominance of GII.4 genotype was also reported in other study in Bahia with children up to 3 years of age with acute gastroenteritis ${ }^{(7)}$.

The strains identified in the present study (Brazil/2009/ KF307752.1, Brazil/2009/KF307753.1, Brazil/2009/KF307754.1, Brazil/2010/KF307755.1, Brazil/2010/KF307756.1, Brazil/2010/ KF307757.1, Brazil/2012/KF265495.1, Brazil/2012/KF265496.1, Brazil/2012/KF265497.1) and previous identified by our group in 2006 (Brazil/2006/EU494638.1, Brazil/2006/EU494651.1, Brazil/2006/EU494653.1) formed a distinct, well-supported clade (bootstrap value D 100). Interestingly, the phylogenetic position of these strains obtained in Salvador demonstrated that these strains have similarity with GII.4 variants circulating around the world. Since 1995, NoV GII.4 was the most prevalent genotype worldwide because of your extensive genetic diversity and every 2 to 3 years new GII.4 variants have emerged, such as US95/96 strain in 1995, Farmington Hills in 2002, Hunter in 2004, GII.4 Den Haag2006b in 2006, New Orleans 2009 in 2009 and Sydney 2012 in $2012^{(14,15)}$. In Brazil, different variants were detected circulating in Northeast, South and Southeast regions during the period 2004-2012. The first variant detected was Asia 2003 in 2004 (described as a recombinant strain), followed by Hunter 2004, Farmington Hills, Yerseke 2006a, Den Haag 2006b, New Orleans 2009 and Sydney 2012. However, it was observed that the variants circulating in Brazil spread and were replaced by different dynamics ${ }^{(16)}$.

In this study, the phylogenetic tree topology shows that the strains previously identified in Bahia in 2006 (Brazil/2006/ 
EU494638.1, Brazil/2006/EU494651.1, Brazil/2006/EU494653.1) form a cluster with the strain USA/2002/AY502023.1, defined in GenBank as GII.4 Farmington Hills. The strains circulating in 2009(Brazil/2009/KF307752.1, Brazil/2009/KF307753.1, Brazil/2009/KF307754.1) form a cluster with the strain Bulgaria/2010/ KP762408.1 (bootstrap value D 95), suggesting that these strains are Den Haag 2006b. This variant was detected circulating for the first time in Brazil in 2006, was the predominant strain during the period of 2006-2008 and was observed co-circulating with Yerseke 2006a during 2008-2009 ${ }^{(16)}$. The strains circulating in 2010 (Brazil/2010/ KF307755.1, Brazil/2010/KF307756.1, Brazil/2010/KF307757.1) form a cluster with a New Orleans 2009 variant (South Africa/2009/ KR904808.1 and South Africa/2009/KR904564.1). In Brazil this variant was first detected in 2009 and was observed circulating until 2011 , being subsequently replaced by the Sydney 2012 variant in $2012^{(16)}$, as observed in this study, where strains circulating in 2012 (Brazil/2012/KF265495.1, Brazil/2012/KF265496.1, Brazil/2012/ KF265497.1) form a cluster with China/2012/KJ196283.1 and Australia/2012/JX459908.1 (bootstrap value D 98).

\section{CONCLUSION}

This is the first report of NoV GII.4 variants in Bahia. The identification of different NoV strains is a significant public concern, considering that the new strains are often associated with new outbreaks of gastroenteritis. In addition, they are often more virulent than the previous one and may lead more severe clinical manifestations, mainly in children, elderly and immunocompromised patients. These findings reinforce the need to study the molecular epidemiology of NoV infections in acute gastroenteritis. Further studies are necessary in order to identification the NoV in other parts of the country and identificate the genetic variability of this virus. Finally, the development of a national database of Brazilian strains of NoV could provide greater insight into the virus and its epidemiological impact on the population, as seen in the European countries that have the NoroNet, a database who share surveillance and research data on Norovirus.

\section{ACKNOWLEDGEMENTS}

Author's would like to thank Dr. Claudio José de Freitas Brandão from the Aliança Hospital for sample donation.

\section{Authors' contribution}

Sardi SI and Campos GS: conception and design of research; Paula FL: performed experiments, analyzed data, interpreted results of experiments, drafted manuscript; Tigre, DM and Fernandes FMC: analyzed data, interpreted results of experiments; Paula FL, Sardi SI and Campos GS: edited, revised and approved final version of manuscript.

Paula FL, Sardi SI, Tigre DM, Fernandes FMC, Campos GS. Gastroenterite aguda associada a variantes do Norovírus GII.4. Arq Gastroenterol. 2018;55(3):264-6.

RESUMO - Contexto - Norovírus (NoV) é o agente etiológico mais importante nas gastroenterites agudas e infecta indivíduos de todas as idades, especialmente crianças no Brasil e no mundo. O NoV GII.4 é o genótipo mais prevalente em todo o mundo devido a sua elevada diversidade genética. No Brasil, principalmente no Nordeste, poucos estudos têm sido desenvolvidos a fim de identificar e caracterizar molecularmente o NoV. Objetivo - O presente estudo teve como objetivo detectar e descrever a epidemiologia molecular do NoV associado com gastroenterite aguda. Métodos - RNA viral extraído a de amostras de fezes foi submetido a amplificação por Nested-RT-PCR e o genótipo determinado por analise da sequência de nucleotídeos. Um total de 278 amostras de pacientes atendidos no Hospital Aliança, na cidade de Salvador, com gastroenterite aguda foram examinados, entre março de 2009 a julho de 2012. Resultados - Uma alta taxa de NoV (54,2\%) foi identificado em crianças de até 5 anos de idade. Detectou-se a circulação de diferentes variantes de NoV GII.4 em Salvador, durante o período do estudo, tais como Den Haag 2006b, New Orleans 2009 e Sydney 2012. Conclusão - Estes achados reforçam a necessidade de maiores estudos para esclarecer a epidemiologia molecular das infecções por NoV em casos de gastroenterite aguda.

DESCRITORES - Norovirus. Gastroenterite. Filogenia.

\section{REFERENCES}

1. Robilotti E, Deresinski S, Pinsky BA. Norovirus. Clin Microbiol Rev. 2015;28:134-64

2. Thorne LG, Goodfellow IG. Norovirus gene expression and replication. J Gen Virol. 2014;95:278-91

3. Kroneman A, Vega E, Vennema H, Vinjé J, White PA, Hansman G, et al. Proposal for a unified norovirus nomenclature and genotyping. Arch Virol. 2013:158:2059-68.

4. Gallimore CI, Barreiros MAB, Brown DWG, Nascimento JP, Leite JPG. Noroviruses associated with acute gastroenteritis in a children's day care facility in Rio de Janeiro, Brazil. Braz J Med Biol Res. 2004;37:321-6.

5. Borges AMT, Teixeira JMS, Costa PSS, Giugliano LG, Fiaccadori FS, Carvalho e Franco R, et al. Detection of calicivirus from fecal samples from children with acute gastroenteritis in the West Central region of Brazil. Mem Inst Oswaldo Cruz. 2006;101:721-4

6. Campos GS, Moreau VH, Bandeira A, Barberino G, Almeida PF, Amador DM, et al. Molecular detection and genetic diversity of norovirus in hospitalized young adults with acute gastroenteritis in Bahia, Brazil. Arch Virol. 2008;153:1125-9.

7. Xavier MPTP, Oliveira SA, Ferreira MSR, Victoria M, Miranda V, Silva MFM, et al Detection of caliciviruses associated with acute infantile gastroenteritis in Salvador, an urban Center in Northeast Brazil. Braz J Med Biol Res. 2009;42:438-44.

8. Ferreira MSR, Garcia RCC, Xavier MPTP, Ribeiro RL, Assis RM, Mota MCMS, et al. Genotyping of gastroenteric viruses in hospitalised children: first report of norovirus GII.21 in Brazil. Mem Inst Oswaldo Cruz. 2012;107:1064-7.
9. Siqueira JAM, Linhares AC, Carvalho TCN, Aragão GC, Oliveira DS, Santos $\mathrm{MC}$, et al. Norovirus infection in children admitted to hospital for acute gastroenteritis in Belém, Pará, Northern Brazil. J Med Virol. 2013;85:737-44.

10. Koek AG, Bovée LPMJ, Van den Hoek JAR, Bos AJ, Bruisten SM. Additional value of typing Noroviruses in gastroenteritis outbreaks in Amsterdam, The Netherlands. J Clin Virol. 2006;35:167-72.

11. Tamura K, Stecher G, Peterson D, Filipski A, Kumar S. Mega 6: Molecular evolutionary genetics analysis version 6.0. Mol Biol Evol. 2013;30:2725-9.

12. Payne DC, Vinjé J, Szilagyi PG, Edwards KM, Staat MA, Weinberg GA, et al. Norovirus and medically attended gastroenteritis in U.S. children. N Engl Med. 2013;368:1121-30

13. Ferreira MSR, Xavier MDPTP, Tinga ACDC, Rose TL, Fumian TM, Fialho $\mathrm{AM}$, et al. Assessment of gastroenteric viruses frequency in a children's day care center in Rio De Janeiro, Brazil: a fifteen year study (1994-2008). PLoS ONE. 2012; 7:e33754.

14. Siebenga JJ, Vennema H, Zheng D-P, Vinjé J, Lee BE, Pang X-L, et al. Norovirus illness is a global problem: emergence and spread of Norovirus GII.4 variants, 2001-2007. JID. 2009;200:802-12.

15. Vinjé J. Advances in laboratory methods for detection and typing of Norovirus. J Clin Microbiol. 2015;53:373-81.

16. Fioretti JM, Bello G, Rocha MS, Victoria M, Leite JPG, Miagostovich MP Temporal dynamics of Norovirus GII.4 variants in Brazil between 2004-2012. PLoS ONE. 2014;9:e92988. 